\title{
Analisis Kemampuan Pemecahan Masalah Matematis : Dampak Model Pembelajaran Reciprocal Teaching Dengan Fieldtrip
}

\author{
Jamroni Wibi Darmani ${ }^{1}{ }^{*}$, Achi Renaldi ${ }^{1}$ \\ ${ }^{1}$ Universitas Islam Negeri Raden Intan Lampung. Jalan Endro Suratmin, Sukarame, Bandar \\ Lampung35133, Indonesia \\ *Corresponding Author. E-mail: jamronidarmani@gmail.com
}

Received : 13-08-2018; Revised : 19-09-2018; Accepted : 30-09-2018

\begin{abstract}
Abstrak
Kemampuan pemecahan masalah matematis peserta didik sangatlah penting. Namun hasil obsevasi dan didukung oleh beberapa penelitian kemamuan pemecahan masalah matematis peserta didik masih sangat rendah. Diduga model pembelajaran reciprocal teaching dengan bantuan filedtrip mampu meningkatkan kemampuan pemecahan maslah matematis peserta didik. Penelitian ini bertujuan untuk mengetahui pengaruh penggunaan model reciprocal teaching dengan fieldtrip terhadap kemampuan pemecahan masalah matematis peserta didik. Teknik pengambilan sample yang digunakan adalah cluster random sampling dengan 2 kelas yaitu kelas eksperimen (kelas mendapat perlakuan model pembelajaran reciprocal teaching dengan fieldtrip), dan kelas kontrol (kelas mendapat perlakuan model konvensional). Uji hipotesis yang digunakan adalah uji-t. Hasil penelitian memperoleh bahwa ada perbedaan kemampuan pemecahan maslah matematis peserta didik dengan menggunakan model pembelajaran reciprocal teaching dengan fieldtrip terhadap kemampuan pemecahan masalah matematis peserta didik. Selanjutnya kemampuan pemecahan masalah matematis peserta didik dengan model pembelajaran reciprocal teaching lebih baik dari pada kemampuan pemecahan masalah matematis peserta didik menggunakan model pembelajaran konvensional. Kesimpulan dari penelitian ini adalah terdapat pengaruh dalam meningkatkan kemampuan pemecahan maslaah matematis peserta didik dengan penggunaan model pembelajaran reciprocal teaching dengan fieldtrip terhadap.
\end{abstract}

Kata Kunci: reciprocal teaching dengan fieldtrip, kemampuan pemecahan masalah matematis.

\begin{abstract}
Students' mathematical problem solving ability is very important. But the results of the observation and supported by several studies of students' mathematical problem solving abilities are still very low. It is suspected that reciprocal teaching learning model with the help of tripships can improve students' mathematical problem solving abilities. This study aims to determine the effect of using reciprocal teaching models with fieldtrips on students' mathematical problem solving abilities. The sampling technique used was cluster random sampling with 2 classes, namely experimental class (the class was treated with reciprocal teaching learning model with fieldtrip), and the control class (the class was treated by conventional models). The hypothesis test used is the t-test. The results of the study found that there were differences in students 'mathematical problem solving abilities using reciprocal teaching learning models with fieldtrips on students' mathematical problem solving abilities. Furthermore, the mathematical problem solving ability of students with reciprocal teaching learning model is better than the students' mathematical problem solving abilities using conventional learning models. The conclusion of this study is that there is influence in improving students' mathematical problem solving ability by using reciprocal teaching learning model with fieldtrip to.
\end{abstract}

Keywords: reciprocal teaching with fieldtrip, mathematical problem solving abilities 
Desimal, 1 (3), 2018 - 374

Jamroni Wibi Darmani, Achi Renaldi

\section{PENDAHULUAN}

Menurut Ormrod dalam Lei, pemecahan masalah adalah cara dalam menggunakan (yaitu mentransfer) pengetahuan dan keterampilan yang sudah ada untuk menjawab pertanyaan yang belum terjawab atau situasi yang sulit (Lei, 2010). Sehingga Kemampuan pemecahan masalah matematis merupakan salah satu kemampuan dasar matematika yang harus dimiliki oleh setiap peserta didik (Syazali, 2015; Wijayanti \& Sungkono, 2017). Kita biasanya mengasosiasikan pemecahan masalah dengan matematika dan sains, namun sebenarnya pemecahan masalah itu dapat terjadi secara nyata pada semua domain konten (content domain). Pemecahan masalah merupakan pusat pembelajaran matematika (Widyastuti, 2015). Dengan belajar memecahkan masalah maka peserta didik diberi banyak kesempatan untuk menghubungkan ide matematika dan untuk mengembangkan pemahaman konseptual. Pada kenyataannya, lagi-lagi kemampuan pemecahan masalah dalam matematika tetap menjadi permasalahan yang paling mendasar.

Akan tetapi tak bisa dipungkiri jika kemampuan pemecahan masalah matematis peserta didik masih belum menggembirakan. Pada beberapa penelitian yang telah dilakukan yang menyatakan bahwa kemampuan pemecahanan masalah matematis peserta didik masih rendah. Seperti yang diungkapkan oleh putra dalam penelitiannya yang dilakukan di SMP Negeri 1 Pematang bahwa kemampuan pemecahan masalah matematis peserta didik masih tergolong rendah (Gusnidar, Netriwati, \& Putra, 2018; Putra, 2017). Rendahnya kemampuan pemecahan masalah matematis peserta didik diduga dipengaruhi oleh penerapan model pembelajaran yang digunakan oleh guru(Mujib, 2016).
Pemilihan model pembelajaran yang tepat akan membantu peserta didik dalam memahami materi dengan lebih baik(Agustiana, Putra, \& Farida, 2018; Mardhiyana \& Jailani, 2017). Agar peserta didik mampu memecahkan masalah yang dihadapi dalam kegiatan belajar, maka peserta didik harus lebih tekun dan giat dalam belajarnya(Prabawanti, 2015). Oleh karena itu, kemampuan pemecahan masalah matematis sangat diperlukan bagi setiap peserta didik dalam pembelajaran matematika karena kemampuan pemecahan masalah matematis yang diperoleh dalam pembelajaran matematika dapat digunakan dan diterapkan dalam memecahkan atau menyelesaikan masalah di kehidupan sehari-hari (Yuliasari, 2017). Maka dari itu, untuk mempermudah peserta didik dalam menguasai kemampuan pemecahan masalah dalam proses belajar dibutuhkan model pembelajaran yang tepat dan sesuai dengan materi pembelajaran (Yuliasari, 2017). Salah satu model pembelajaran kooperatif yang dapat digunakan adalah model pembelajaran Reciprocal Teaching.

Model pembelajaran Reciprocal Teaching merupakan adalah suatu pendekatan pembelajaran yang menerapkan empat strategi pemahaman mandiri, yaitu menyimpulkan bahan ajar, menyusun pertanyaan dan menyelesaikannya, menjelaskan kembali pengetahuan yang telah diperolehnya, kemudian memprediksikan pertanyaan selanjutnya dari persoalan yang disodorkan kepada siswa. Sehingga peserta didik dapat meningkatkan antusias siswa dalam pembelajaran karena siswa dituntut untuk aktif berdiskusi dan menjelaskan hasil pekerjaannya dengan baik sehingga penguasaan konsep dan kemampuan dalam menyelesaikan masalah suatu pokok bahasan matematika dapat dicapai (Rachmayani, 2014). Hal ini didukung oleh (Noriasih, 2013)yang menyatakan bahwa penerapan model pembelajaran reciprocal teaching dapat mengembangkan gagasan dalam pemecahan masalah, selain itu peserta didik menjadi lebih kreatifitas didalam pembelajarannya. Merujuk 
penelitian oleh (Setiawan, Corebima, \& Zubaidah, 2013) bahwa model reciprocal teaching mampu mengoptimalakan kemampuan peserta didik dalam memecahkan masalah dengan cara membebaskan peserta didik menemukan halhal baru dan memperoleh pengalaman secara langsung di lapangan sehingga peserta didik akan merasa tidak diberatkan dengan beban dan paksaan. Sejalan dengan paparan oleh (Sutarmi, Suharsono, \& Warpala, 2013) bahwa terjun kelapangan (lingkungan sekitar) dengan cara mengamati akan mampu merangsang kemampuan-kemampuan yang ada didalam peserta didik. Merujuk dengan hal itu maka penulis akan fieldtrip dalam menerepkan model yang direkomendasikan yaitu reciprocal teaching. Diduga model pembelajaran reciprocal teaching akan lebih optimal dengan melakukan fieldtrip dalam meningkatkan kemampuan pemecahan masalah matematis peserta didik. Metode fieldtrip sendiri merupakan metode yang mengajak peserta didik untuk langsung terjun kelapangan sesuai dengan materi pelajaran yang sedang dipelajari (Rahmawati, 2008).
Berdasarkan hasil penelitian (Yuliati \& Martuti, 2014).menunjukan bahwa kunjungan kelapangan dapat memberikan pengalaman yang efektif dalam menyelesaikan masalah serta meningkatkan motivasi belajar peserta didik. Berdasarkan hal ini penulis akan melakukan penelitian dengan tujuan untuk melihat pengaruh model Recirocal teaching dengan melakukan fieldtrip terhadap kemampuan pemecahan maslah matematis peserta didik. Penggunaan fieldtrip ini sekaligus keterbaharuan penulis dari penelitian-penelitian sebelumnya (Efendi, 2013; Noriasih, 2013; Rachmayani, 2014; Setiawan et al., 2013).

\section{METODE}

Metode penelitian yang digunakan pada penelitian ini adalah menggunakan penelitian eksperimen karena penulis akan mencari perbedaan treatment (perlakuan) tertentu. Desain penelitian yang akan digunakan adalah PosttestPretest Control Group Design.

\section{Tabel 1. Rancangan Penelitian Eksperimental}

\begin{tabular}{cc}
\hline Pendekatan Pembelajaran & Kelas \\
Model Reciprocal teaching dengan melakukan fieldtrip $\left(\mathrm{a}_{1}\right)$ & Eksperimen $\mathrm{n}_{1} \mathrm{~b}_{1}$ \\
Metode konvensional $\left(\mathrm{a}_{2}\right)$ & Kontrol $\left(\mathrm{b}_{2}\right)$ \\
\hline
\end{tabular}

Populasi dari penelitian ini adalah seluruh peserta didik kelas VIII MTs AlIkhlas Tanjung Bintang. Teknik pengambilan sample yang digunakan adalah probability sampling dengan teknik acak kelas. Kelas eksperimen didapatkan kelas VIII-E (Perlakuan model pembelajaran superitem berbantuan scaffolding) dan kelas control didapatkan kelas VIII-C (perlakuan metode ceramah). Teknik pengumpulan data menggunakan model dokumentasi dan model tes. Model dokumentasi digunakan untuk memperoleh kemampuan awal kelas eksperimen dan kontrol. Sedangkan model tes digunakan untuk memperoleh data mengenai hasil belajar siswa. Model tes digunakan untuk mengumpulkan data kemampuan pemecahan masalah matematis peserta didik dengan tes berbentuk essay/uraian. Tes diberikan setelah memenuhi validitas soal dan diuji cobakan terlebih dahulu di kelas VIII-A untuk melihat tingkat kesukaran dan daya pembeda butir soal tersebut, serta uji reliabilitas terhadap masing-masing instrumen tes.

Sebelum dilakukan uji hipotesis, terlebih dahulu dilakukan uji prasyarat analisis pada kemampuan awal siswa masing-masing kelas uji keseimbangan dengan taraf signifikansi 0.05. Uji prasyarat analisis yaitu uji normalitas menggunakan uji Lillifors dan uji homogenitas Jika hasil uji berdistribusi normal dan berasal dari daerah varians yang sama maka dilakukan uji Hipotesis 
Statistik menggunakan uji-t hipotesis yang digunakan:

$\begin{array}{rlr}\mathrm{H}_{0}: \mu_{1} \leq \mu_{2} \quad & \text { Rata-rata } & \text { peningkatan } \\ & \text { kemampuan pemecahan } \\ & \text { masalah matematis peserta } \\ & \text { didik yang belajar dengan } \\ & \text { model } & \text { pembelajaran } \\ & \text { reciprocal teaching dengan } \\ & \text { melakukan fieldtrip kurang } \\ & \text { dari sama dengan hasil rata- } \\ & \text { rata } & \text { kemampuan } \\ & \text { pemecahan } & \text { masalah } \\ & \text { matematis yang belajar } \\ & \text { dengan } \text { pembelajaran } \\ & \text { biasa) } & \\ & & \text { (Rata-rata peningkatan } \\ \mathrm{H}_{1}: \mu_{1}> & \text { kemampuan pemecahan } \\ & \text { masalah matematis peserta } \\ & \text { didik yang belajar dengan }\end{array}$

model pembelajaran reciprocal teaching dengan melakukan fieldtrip lebih dari hasil rata-rata kemampuan pemecahan masalah matematis yang belajar dengan pembelajaran biasa)

\section{HASIL DAN PEMBAHASAN}

Setelah data hasil belajar peserta didik terkumpul baik dari kedua kelas, baik kelas eksperimen (Perlakuan model reciprocal teaching dengan fieldtrip) maupun dari kelas kontrol (Perlakuan metode ceramah) diperoleh maka diperoleh hasil terlihat pada Tabel 2 .

Tabel 2. Deskripsi Data tes kemampuan pemahaman konsep peserta didik

\begin{tabular}{|c|c|c|c|c|c|c|c|}
\hline \multirow[t]{2}{*}{ Kelas } & \multirow[t]{2}{*}{$\mathbf{X}_{\text {maks }}$} & \multirow[t]{2}{*}{$\mathbf{X}_{\min }$} & \multicolumn{3}{|c|}{ Ukuran Tendensi sentral } & \multicolumn{2}{|c|}{$\begin{array}{l}\text { Ukuran variansi } \\
\text { kelompok }\end{array}$} \\
\hline & & & $\bar{x}$ & Me & Mo & & Sd \\
\hline Eksperimen & 90 & 75 & 86,8 & 85 & 90 & 15,06 & 3,7 \\
\hline Kontrol & 85 & 60 & 71,3 & 70 & 70 & 44,4 & 6,6 \\
\hline
\end{tabular}

Tabel 2 menggambarkan hasil setelah dilaksanakan pembelajaran, pada kelas eksperimen maupun dari kelas kontro) dilakukan evaluasi akhir untuk mengetahui hasil belajar peserta didik sebagai pengumpulan data hasil evaluasi akhir diperoleh nilai tertinggi pada kelas eksperimen yaitu sebesar 90 dan kelas kontrol yaitu sebesar 85 , sedangkan nilai terendah untuk kelas eksperimen adalah 75 dan kelas kontrol adalah 60. Ukuran tendensi sentral yang meliputi rata-rata kelas (mean) untuk kelas eksperimen sebesar 86,8 dan kelas kontrol sebesar 71,3 sementara untuk nilai tengah kelas kelas eksperimen yaitu sebesar 85 dan kelas kontrol yaitu sebesar 70, sedangkan modus dikelas eksperimen adalah 90 dan kelas kontrol adalah 70 . Ukuran variansi kelompok meliputi jangkauan atau rentang untuk kelas eksperimen adalah 15,06 dan kelas kontrol adalah 44,4. Simpangan baku kelas eksperimen sebesar 3,7dan kelas kontrol 6,6. Berdasarkan hal ini dapat disimpulkan bahwa hasil belajar peserta didik kelas eksperimen ((Perlakuan model reciprocal teaching dengan fieldtrip) lebih baik dari kelas kontrol (Perlakuan metode ceramah).

Selanjutnya dilakukan analisis uji asumsi dengan uji normalitas tes kemampuan pemahaman konsep peserta didik pada kelas eksperimen dengan hasil skor kelas eksperimen dengan $L_{\text {hitung }}=$ ,0,125 dan $L_{\text {tabel }}=0,133$ hal ini menunjukan bahwa $L_{\text {hitung }}<L_{\text {tabel }}$ sehingga dapat disimpulkan data 
berdistribusi normal. Dan kelas kontrol dengan $L_{\text {hitung }}=0,134$ dan $\quad L_{\text {tabel }}=$ 0,141 hal ini menunjukan bahwa $L_{\text {hitung }}<L_{\text {tabel }} \quad$ sehingga dapat disimpulkan data berdistribusi normal. Berikut hasil rekapitulasi perhitungan hasil belajar peserta didik pada kelas eksperimen dan kelas kontrol.

Tabel 3. Hasil uji normalitas kemampuan pemecahan masalah matematis

\begin{tabular}{llll} 
Kelas & $\boldsymbol{L}_{\text {hitung }}$ & $\boldsymbol{L}_{\text {tabel }}$ & keterangan \\
Eksperimen & 0,125 & 0,133 & Normal \\
Control & 0,134 & 0,141 & Normal \\
\hline
\end{tabular}

Berdasarkan Tabel 3 perhitungan hasil uji coba normalitas hasil belajar matematik peserta didik Kemampuan pada kelas eksperimen dan kelas kontrol dengan taraf sigifikansi $\alpha=0,05$, diperolah bahwa nilai dari $L_{\text {hitung }}$ dari setiap kelompok kurang dari $L_{\text {tabel }}$ sehingga hipotesis nol dari setiap kelompok diterima. Dapat disimpulkan bahwa data yang diperoleh dari setiap kelompok berasal dari populasi yang berdistribusi normal.
Untuk mengetahui apakah kedua skor memiliki karakter yang sama atau berbeda maka diperlukan uji F. Pengujian variansi ini yaitu membandingkan varians terbesar dan varians terkecil. Jika $F_{\text {hitung }} \leq F_{\text {tabel }}\left(\sigma_{1}, \sigma_{2}\right) \quad$ didapat dari distribusi dengan peluang $\frac{1}{2} \alpha$ sedangkan derajat kebebasan $\sigma_{1}\left(n_{1}-1\right)$ dan $\sigma_{2}\left(n_{2}-\right.$ 2) masing-masing sesuai dengan $d k$ pembilang dan $d k$ penyebut. Hasil pengujian varians dengan taraf signifikan $\alpha=0,05$ dapat dilihat pada Tabel 4 .

Tabel 4. Hasil Perhitungan Uji Kesamaan Dua Varians

\begin{tabular}{ccccc}
\hline Kelas & Jumlah Sempel & $\boldsymbol{F}_{\text {hitung }}\left(L_{(\alpha, n)}\right)$ & $\boldsymbol{F}_{\text {tabel }}$ & Keterangan \\
$\begin{array}{c}\text { Eksperimen } \\
\text { kontrol }\end{array}$ & 44 & 3,16 & 1,73 & Tidak Homogen \\
\hline
\end{tabular}

Berdasarkan Tabel 4 Hasil perhitungan skor Kemampuan Pemahaman konsep matematis diperoleh $F_{\text {hitung }}=3,16$ dan $F_{\text {tabel }}=1,73$. Menunjukan bahwa $F_{\text {hitung }}<F_{\text {tabel }}$ dengan hal ini dapat disimpulkan bahwa $H_{0}$ diterima atau sampel berasal dari populasi yang memiliki varians sama. Untuk menguji perbedaan hasil belajar matematis peserta didik digunakan rumus uji-t, karena data yang diperoleh berdistribusi normal dan memiliki nilai varians sama. Hasil perhitungan dapat dilihat pada Tabel 5 . berikut ini :

Tabel 5. Hasil Perhitungan Uji-t

\begin{tabular}{cccccc}
\hline Kelas & Jumlah Sempel & Rata-Rata $(\boldsymbol{x})$ & $\boldsymbol{t}_{\text {tabel }}\left(\boldsymbol{t}_{\boldsymbol{a}, \boldsymbol{d} \boldsymbol{b}}\right)$ & $\boldsymbol{t}_{\text {hitung }}$ & Keterangan \\
Eksperimen & 44 & 86,8 & 3,17 & \multirow{2}{*}{1,66} & Terima $\mathrm{H}_{0}$ \\
Kontrol & 34 & 71,3 & & \\
\hline
\end{tabular}


Berdasarkan Tabel 5. perhitungan diperoleh $\boldsymbol{t}_{\text {hitung }}=1,66$ dan $\boldsymbol{t}_{\text {tabel }}=$ 3,17 sehingga $\boldsymbol{t}_{\text {hitung }}>\boldsymbol{t}_{\text {tabel }}$, yang berarti $\mathrm{H}_{0}$ ditolak. Dilihat dari rata-rata hasil belajar peserta didik dapat dilihat pada tabel 4 diperoleh kelas eksperimen (kelas yang mendapat perlakuan reciprocal teaching dengan fieldtrip) memperoleh nilai 86,8 yang sedangkan kelas kontrol (kelas yang mendapat perlakuan model ceramah) memperoleh nilai 71,3, Dengan hasil analisis ini dapat disimpulkan bahwa ada perbedaan yaitu kemampuan pemecahan masalah matematis peserta didik peserta didik antara kelas eksperimen (kelas yang mendapat perlakuan reciprocal teaching dengan fieldtrip) lebih baik dari pada kemampuan pemecahan masalah matematis peserta didik kelas kontrol (kelas yang mendapat perlakuan model ceramah). Hasil penelitian ini sama dengan hasil penelitian sebelumnya dengan hasil bahwa model penelitian reciprocal teaching dengan fieldtrip mampu membantu meningkatkan kemampuan pemecahan maslah matematis peserta didik dalam proses belajar atau mengaitkan pembelajaran dalam kehidupan

\section{KESIMPULAN DAN SARAN}

Berdasarkan hasil analisis dan pengolahan data serta mengacu pada perumusan masalah yang telah diuraikan, maka dapat disimpulkan bahwa: terdapat pengaruh kemampuan pemecahan maslah matematis peserta didik dengan penerapan model pembelajaran strategi pembelajaran reciprocal teaching dengan fieldtrip. Selanjutnya kemampuan pemecahan masalah matematis peserta didik dengan strategi pembelajaran reciprocal teaching dengan fieldtrip lebih baik daripada model pembelajaran konvensional (ceramah).

Berdasarkan kesimpulan di atas maka penulis mamberikan saran sebagai berikut. (1) Lembaga pendidikan khususnyadapat menerapkan strategi pembelajaran reciprocal teaching dengan fieldtrip untuk melatih peserta didik ikut serta dalam proses pembelajaran dalam meningkatkan kemampuan pemecahan masalah matematis peserta didik. (2) untuk penelitian yang serupa atau lebih lanjut perlu diobservasikan terlebih dahulu model pembelajaran yang penah diterima oleh peserta didik sehingga penerapan strategi pembelajaran reciprocal teaching dengan fieldtrip dapat berjalan dengan baik. Semoga apa yang diteliti dapat dilanjutkan oleh penulis lain dengan penelitian yang lebih luas. Harapan penulis yang lain adalah apa yang diteliti dapat memberikan manfaat dan sumbangan pemikiran bagi pendidik pada umumnya dan penulis pada khususnya.

\section{DAFTAR PUSTAKA}

Agustiana, E., Putra, F. G., \& Farida, F. (2018). Penerapan Model Pembelajaran Auditory, Intellectually, Repetition (AIR) dengan Pendekatan Lesson Study terhadap Kemampuan Pemecahan Masalah Matematis Peserta Didik. Desimal: Jurnal Matematika, 1(1), 16.

Efendi, N. (2013). Pengaruh pembelajaran reciprocal teaching dipadukan think pair share terhadap peningkatan kemampuan metakognitif belajar biologi siswa SMA berkemampuan akademik berbeda di kabupaten sidoarjo. Jurnal Santiaji Pendidikan (JSP), 3(2), 85-109.

Gusnidar, G., Netriwati, N., \& Putra, F. G. (2018). Implementasi Strategi Pembelajaran Konflik Kognitif Berbantuan Software Wingeom Dalam Meningkatkan Kemampuan Pemecahan Masalah Matematis. 
Jurnal Edukasi Matematika Dan Sains, 5(2), 62-69.

Lei, S. A. (2010). Intrinsic and extrinsic motivation: Evaluating benefits and drawbacks from college instructors' perspectives. Journal of Instructional Psychology, 37(2), 153-161.

Mardhiyana, D., \& Jailani, J. (2017). Pengembangan model asesmen pembelajaran matematika SMA berdasarkan kurikulum 2013. Pythagoras: Jurnal Pendidikan Matematika, 12(2), 135-148.

Mujib, M. (2016). Mengembangkan Kemampuan Berfikir Kritis Melalui Metode Pembelajaran Improve. AlJabar: Jurnal Pendidikan Matematika, $7(2), 167-180$.

Noriasih, N. K. (2013). Pengaruh Model Pembelajaran Reciprocal Teaching terhadap Pemahaman Bacaan ditinjau dari Konsep Diri Akademik Siswa. Jurnal IKA, 11(2).

Prabawanti, E. S. (2015). Penerapan Model Pembelajaran Quantum Teaching dengan Metode Diskusi Berbantuan Lembar Kerja Siswa (LKS) untuk Meningkatkan Hasil Belajar Materi Bentuk Pangkat dan Akar pada Siswa Kelas X. 6 Semester I SMA Negeri 2 Magetan Tahun Pelajaran 2013/2014. Jurnal Ilmiah Pendidikan Matematika, 3(2), 390-397.

Putra, F. G. (2017). Eksperimentasi Pendekatan Kontekstual Berbantuan Hands On Activity (HoA) Terhadap Kemampuan Pemecahan Masalah Matematik. Al-Jabar: Jurnal Pendidikan Matematika, 8(1), 73-80. https://doi.org/10.24042/ajpm.v8i1 .1148

Rachmayani, D. (2014). Penerapan Pembelajaran Reciprocal Teaching untuk meningkatkan kemampuan komunikasi matematis dan kemandirian belajar matematika siswa. JUDIKA Uurnal Pendidikan Unsika), 2(1).

Rahmawati, T. (2008). Peningkatan
Keterampilan Menulis Dengan Metode berkunjung ke Lingkungan Sekitar (Field Trip) Pada Siswa Kelas V SD Negeri I Kulurejo Kecamatan Nguntoronadi Kabupaten Wonogiri Tahun ajaran 2007/2008. Skripsi: UNS.

Setiawan, D. C., Corebima, A. D., \& Zubaidah, S. (2013). Pengaruh Strategi Pembelajaran Reciprocal Teaching (RT) Dipadu Pemberdayaan Berpikir Melalui Pertanyaan (PBMP) terhadap Kemampuan Metakognitif Biologi Siswa SMA Islam Al-Ma'arif Singosari Malang. In Proceeding Biology Education Conference: Biology, Science, Enviromental, and Learning (Vol. 10, pp. 195-201).

Sutarmi, N. W., Suharsono, N., \& Warpala, I. W. S. (2013). Pengaruh pembelajaran Scaffolding terhadap Keterampilan Menulis Teks Recount Berbahasa Inggris dan Kreativitas Siswa Kelas VIII SMP Negeri 3 Manggis. Jurnal Teknologi Pembelajaran Indonesia, 3.

Syazali, M. (2015). Pengaruh Model Pembelajaran Creative Problem Solving Berbantuan Maple II Terhadap Kemampuan Pemecahan Masalah. Al-Jabar: Jurnal Pendidikan Matematika, 6(1), 91-98.

Widyastuti, R. (2015). Proses Berpikir Siswa dalam Menyelesaikan Masalah Matematika berdasarkan Teori Polya ditinjau dari Adversity Quotient Tipe Climber. Al-Jabar: Jurnal Pendidikan Matematika, 6(2), 183-194.

Wijayanti, S., \& Sungkono, J. (2017). Pengembangan Perangkat Pembelajaran mengacu Model Creative Problem Solving berbasis Somatic, Auditory, Visualization, Intellectually. Al-Jabar: Jurnal Pendidikan Matematika, 8(2), 101110.

Yuliasari, E. (2017). Eksperimentasi Model PBL dan Model GDL Terhadap Kemampuan Pemecahan Masalah 
Desimal, 1 (3), 2018 - 380

Jamroni Wibi Darmani, Achi Renaldi

Matematis Ditinjau dari Kemandirian

Belajar. JIPM (Jurnal Ilmiah

Pendidikan Matematika), 6(1), 1-10.

Yuliati, T., \& Martuti, N. K. T. (2014). Efektivitas penerapan metode field trip untuk meningkatkan hasil belajar dan kepedulian siswa terhadap lingkungan. Jurnal Pendidikan Matematika Dan Sains, 2(2), 178-186. 